\title{
LUT
}

Lappeenranta

University of Technology

\section{Using Kaleidoscopic Pedagogy to Foster Critically Reflective Learning About Management and Leadership}

Pässilä Anne, Malin Virpi, Owens Allan

This is a Final draft

version of a publication

published by Palgrave Macmillan, Cham

in Using Kaleidoscopic Pedagogy to Foster Critically Reflective Learning About Management and Leadership. In: Antonacopoulou E., Taylor S. (eds) Sensuous Learning for Practical Judgment in Professional Practice.

DOI: 10.1007/978-3-319-99049-1_11

Copyright of the original publication: (C) 2019 Springer Nature Switzerland AG

Please cite the publication as follows:

Pässilä A., Malin V., Owens A. (2019) Using Kaleidoscopic Pedagogy to Foster Critically Reflective Learning About Management and Leadership. In: Antonacopoulou E., Taylor S. (eds) Sensuous Learning for Practical Judgment in Professional Practice. Palgrave Studies in Business, Arts and Humanities. Palgrave Macmillan, Cham. DOI: 10.1007/978-3-319-99049-1 11

This is a parallel published version of an original publication. This version can differ from the original published article. 
FINAL DRAFT/author's accepted manuscript

Pässilä, A., Malin, V. and Owens, A. (2019) Using Kaleidoscopic Pedagogy to Foster Critically Reflective Learning about Management and Leadership In E. Antonacopoulou \& S. S. Taylor (eds) Sensuous Learning for Practical Judgment in Professional Practice. Volume 2: Arts-based Interventions. Palgrave Macmillan Springer Nature. pp. 277-302.

\author{
Anne Pässilä, LUT University Lahti Campus, Finland \\ Virpi Malin, University of Jyväskylä, Finland \\ Allan Owens, RECAP, University of Chester, UK
}

\author{
Using Kaleidoscopic Pedagogy to Foster Critically Reflective Learning about \\ Management and Leadership
}

This chapter focuses on the use of Kaleidoscopic Pedagogy in an introductory course of Management and Leadership offered to students considering key concepts and frames of thinking in the field for the first time. We start by introducing the context of the intervention, describe the course and its background and the course facilitators together with some information about the participants. Particular emphasis is placed on the way the course was framed to bring a sense of present day management reality in to the heart of our use of arts based methods through ongoing collaboration with the experience $R \& D$ manager who is part of the course team. Next a consideration of the underlying assumptions and values of the course, embedded in the concept of Kaleidoscopic pedagogy and principles of learning informing it. This is followed by a thick description of a selection of the arts based methods and materials used together with a consideration of the values and purposes underlying these. The impact and experiences of learning during the intervention are then discussed from the students' perspective and the academic/tutors'. In the closing section focus is placed on lessons learned about Kaleidoscopic Pedagogy for practitioners.

\title{
The Context of the Intervention
}

The intervention took the form of a one week course of 24 hours intensive workshops plus 76 hours of independent study arranged by the Jyväskylä University School of Business and Economics (JSBE) as part of the International Summer School in Human Sciences. The Summer School in Human Sciences comprises interdisciplinary courses in culture studies, education, psychology, communication, sport \& health and social sciences offering students world-wide a possibility of 1 to 4 weeks living and learning in an international atmosphere. The course "Introduction to Management and Leadership" (4 ECTS) has been in the program since 2015. The similar course on the same name offered in Finnish and English is one of the most popular bachelor's level courses at JSBE reaching about 500 students every year. Due to the number of students the regular courses are lectured on a traditional basis and for passing the course the students take an exam. When the organizers of the Summer School asked one of the authors to start running the course as part of the Summer School program for a considerably smaller number of students, it gave the possibility to arrange the course in an intensive workshop mode based on creative ways of working and studying.

To summarise, the students involved in the arts based intervention in this study are 
international travelling to Finland from all continents and representing a variety of fields from sports management to history, sociology, mathematics and many others as their major. No prior studies in management and leadership are required - all that is needed is an interest in exploring the theoretical and practical understanding of management and leadership in organizations. In the last three years the number of students on this one week International Summer School has varied from 15 to 20 per year. The vast heterogeneity of the students with regard to cultural and study background has been especially fruitful with regard to criticality and reflexivity goals of the Kaleidoscopic model. The quality of dialogue has reached the level far beyond the expectations of the authors and enabled learning not only together but also from each other. The same goes with the student expectations according to the feedback introduced later in this chapter.

The course has been run and developed from the beginning drawing on extensive experience of the authors in using arts based methods in higher education and a wide range of workplace contexts. Two of the four course tutors are internationally acknowledged forerunners in the use of arts based methods and pedagogy moving between the academy and public, private and third sector organizations; one is the pedagogical director responsible for educational development in a large business school with an interest in creative ways of working and critical management studies; the fourth member of the team is an experienced R\&D manager specialized in innovation management in one of the largest state-run organizations in Finland.

Aesthetic approaches and various forms of arts based methods are no longer solely the domain of arts education but are being increasingly used also in business and management education (Adler, 2015; Meisiek and Barry, 2014b). In the complex world of business the call for creativity and innovation challenge the traditional ways of thinking and doing leaving space for new approaches, which various forms of arts based methods has to offer. The course has deliberately been planned in order to give the students the possibility to step away from the comfort zone and enhance their learning beyond the subject. In this chapter we share our experiences in running and developing a course that is planned and delivered using a Kaleidoscopic model of pedagogy.

\section{Practice-based experiences and the challenges of a leader}

The introduction to management and leadership course is one strategy related to the authors long-term vision of the use of arts based learning in organizations and the resonances and impact this has. The course is not about testing a set of specific tools that can then be applied in all future courses, it is rather about exploring, researching and developing a form of pedagogy that speaks clearly to the needs of and practices in contemporary organizations. It is also concerned with identifying the practices that might be needed in the future whilst acknowledging that we have little awareness of what these or the needs that drive them might be. We are particularly concerned with the use of arts based methods in the context of Management Education training and practices to offer possibilities of exploring organizational behavior, cultural codes, processes, structures and ways of practicing, as well as the underlying professional values, attitudes and assumptions of practice.

As course organizers we ask each other what skills are needed in leadership in present day innovation processes? It is for this reason that we have been working with an experienced $R \&$ D Manager for one of the biggest state- owned companies in Finland. Working with her over 
the last three years on the use of arts based methods enables us to see the challenges being faced currently by public and private companies in the Nordic setting where strong political directives sit in tension with advancing privatization. For example, she shares insights rooted in everyday realities about the ways that organizations are dealing with complex issues, perplexed situations and confusion while simultaneously needing to maintain a sense of purpose and conviction that everything is possible, that the future will be better that the present.

Our R\&D team members experience brings organization management reality in to the heart of our use of arts based methods, in this case in the course introducing management and leadership. Her experience speaks to micro and macro level practices, both of which include a strong relational dimension, how in other words workers in organizations actually make things with others how they inspire and motivate each other and on an increasingly important micro level, how they actually survive in organizations caught increasingly in the tension created between the individual and the system; a tension in the sense that the worker in an organizational setting often assumes individual responsibility for systems level complex issues. We see the contribution of arts-based pedagogy in this context as being about collectively reflecting together on 'what is' in order to increase understanding of current practices. At the same time, collective reflection through arts based pedagogy considers the 'what if' of possible future worlds, and explores the implications of this in situ as well as in a broader frame on the macro level.

The leadership course is not a one-off moment of collaboration, but part of an ongoing series of joint work through which we have been developing different arts-based methods together in the context the R\&D Manager's large public organization. Our course planning has incorporated her experiences in the form of case examples through which she has brought the practice-based experiences and challenges of her role as a leader in an innovation management context. The leadership course is thus one stage within a bigger ongoing arc of activity in the field of arts based pedagogy in the organizational context. One practical and strategic goal of this being to establish ongoing regular programs of arts-based methods in research assessment and evaluation that are accredited (Beyond Text, 2016-2019).

\section{Arts Based Methods}

The Arts Based Methods used in multi-modal combination in this course consisted of: Reflexive Sketch books (Pässilä, Owens, Oikarinen, Kuusipalo-Määttä and Benmergui, 2017) Work Story \& Theatrical Images (Pässilä, 2012), Storytelling (Pässilä, Oikarinen and Kallio, 2013) and embodied interpretation (Pässilä, Lehto, Laukkanen, Owens, and Benmergui, accepted 2017) Before this we present an account of the structure and content of the intervention, the context in which it was performed and the particularities of our conceptualizations of arts based methods, Kaleidoscopic pedagogy and understanding itself.

The use of arts based methods in this course cherishes the humanistic values of individuals as important agencies in learning. Emphasis is placed on the relational aspects of reflection where arts based methods trigger critical thinking, embodied doing and playful acting together. We have used the term 'Turning to Learning' in a previous practice-based study (Pässilä, Owens and Pulkki, 2016) to signify the attempt to move beyond the model of arts use in organisations in which particular methods are applied to complex problems in order to achieve short term solutions. We align the arts based methods based nature of Turning to 
Learning with Harmaakorpi and Melkas (2012) concept of practice-based innovation in the Finnish tradition which underlines that a vivid element of practicing innovation is to develop novel approaches, and methods for thinking and acting in a creative and reflective manner in complex situations where organisational members, stakeholders, customers, communities, citizens -and in this case students- are in the midst of action.

The core of arts based methods in this context is concerned with creating space, time and creative encounters between people through arts based for reflection and imagination methods within a broader pedagogical framework. Based on previous studies where collective voicing (Pässilä et al., 2015) has been identified as a path to allow reflexive practice to emerge we also invited in this course a questioning of the taken-for-granted as central part to innovative learning process (Cotter, Pässilä and Vince, 2015; Pässilä and Vince, 2015). We see reflexivity (Pässilä, Oikarinen, and Harmaakorpi, 2013; Sutherland, 2013; Taylor and Ladkin, 2009; Antonacopoulou, 2010) as fundamental within organisational settings therefore as a systematic part of business and economic studies too.

The process of fostering learning among the participants engaged in the way this intervention was designed around critical reflection zones (Pässilä and Vince, 2015; Vince and Reynolds, 2009) in which the interdisciplinary and intercultural nature of the group was employed to generate of polyphonic knowledge through a Kaleidoscopic pedagogical approach (Pässilä, Owens and Pulkki, 2016). The start of this process was to share the thinking behind choosing the metaphor of the kaleidoscope and the word pedagogy. Our rational for choosing the term pedagogy rather than teaching and learning was that it carries the implication that the relationship between the intention of teaching something and act of learning that something is rarely straightforward. We then presented the case that metaphor, though not without its critics can articulate something of the density, complexity and multi-dimensionality of a form of pedagogy that values both, the intuitive and imaginary as well as the analytical and rational.

The organizing construct for this pedagogical approach comes from our reading of scholars who have explored the metaphoric promise of the Kaleidoscope (Gonnami 1998, Gray 1991, Owens, 2014) as a tool for understanding self, others, society, the world and our place in it. In the literature the kaleidoscope is still defined as an optical instrument. It usually consists of three (but can be two or four) reflecting surfaces placed in a tube at particular angles (usually 60 degrees), at one end of which is a small compartment containing pieces of coloured glass; on looking through the tube, numerous reflections of these are seen, producing brightly-coloured symmetrical figures (usually a six-fold symmetry), which can be constantly altered by rotating or turning the tube.

The kaleidoscope as it is known today was invented in 1816 in Scotland by Sir David Brewster who coined the word 'kaleidoscope' from the Greek; 'kalos' meaning beautiful, 'eidos' meaning form and 'skopeo' meaning, to look at (Oxford English Dictionary 1998, Vol. 7, p.342). The idea of the kaleidoscope not being of any 'practical' use in itself, but allowing understandings to be clarified, shaped and shared through the aesthetic in a series of successive phases that hold for a while before the next shift, resonates with our intuitive sense of how understandings are constructed.

The turns in the Leadership course were created to occur on many levels from: the reality of the arts based methods employed to the reality of everyday life; actual worlds to possible worlds, imaginary to rational, analytical to intuitive, conscious. The kaleidoscope turning or 'in this sense '... breaks-up the familiar....it images unfamiliarity...it generates unfamiliarity through 
the process of multiplication or cloning' which is where 'excess meaning' or knowledge creation originates from.

A perceptual chaos framed by order; a rearrangement that disassembles the familiar images of nature by multiplying it through a series of reflections into an unfamiliar pattern...a generative force for visual unfamiliarity...the persistent presence of this nursery plaything...its interest in lawful messiness, its interest in change.

(Gray 1991)

The simplest pieces of coloured glass appear at the far end of the tube in surprising, strange formations, no longer bits of coloured glass but intricate, complex original shapes, the everyday made strange and beautiful. We make the connection between Gray's notion of 'a generative force for unfamiliarity' and Brecht's verfremdungseffekt; the unexamined realities of everyday life rendered strange through powerfully beautiful arts based form. In this sense, the turns in the sessions were envisaged as turns of form, turns of the kaleidoscope, where one arts based method was carefully set off against another traditional teaching method. The process was driven forward by interpretation and questioning to allow for 'adaptive understanding' where,

The understanding you have had before may turn out to be restricted, false, and your learning horizon breaks down into pieces, and you construct a quite new understanding. (Ostern 2001, p.16)

Viewed airily the students on the course move and settle in the space, turned not through a round tube within a triangle of mirrored sides, but through arts based methods circling around the given subject of management and leadership. As educators we are the ones who turn'- to 'look at from many angles' and this is how we conceptualized our work alongside the participants, imagining, interpreting, expounding the significance of, expressing one thing in terms of another, trying to articulate changing understandings of management and leadership.

Reflecting on this process after three runs of the course $(2015,2016,2017)$ we make sense of the ingredients that are expressed in the kaleidoscopic model between 6 points of reference: imagination, doing and acting, knowledge and knowing, participation, transforming and understanding possibilities. 


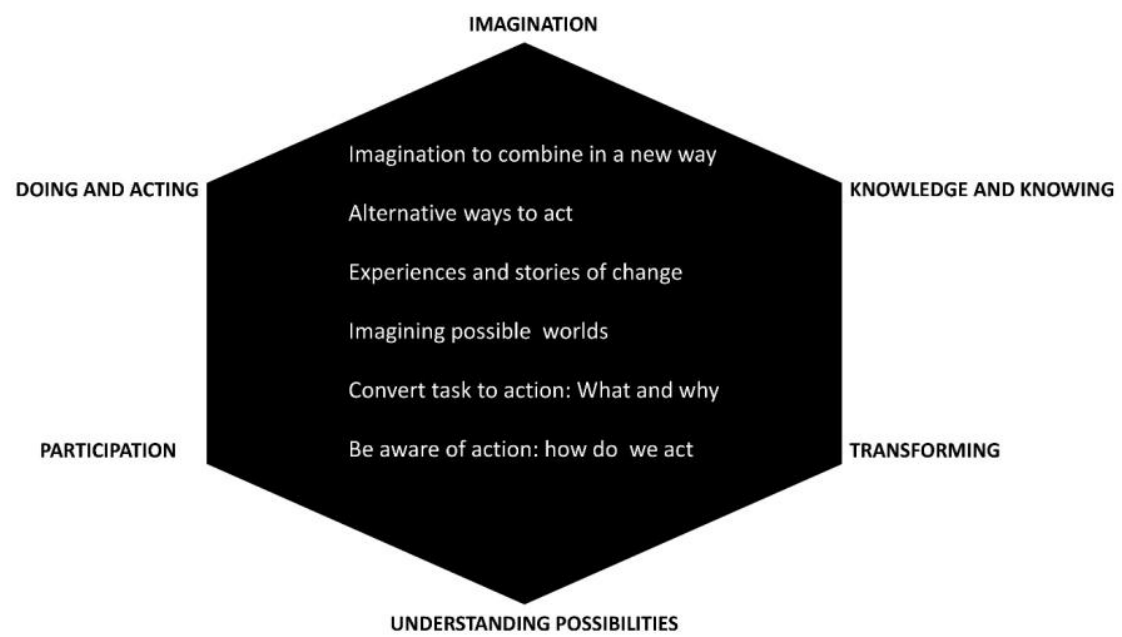

Image 1 Kaleidoscopic model of pedagogy

From this emerge the possibilities of using imagination to combine in a new way, experiences and stories of change, imagining possible worlds, converting tasks in to actions, being aware of actions and identifying alternative and ethical ways to act. Instead of focusing on finding solid answers, the inspiration is to find through different voices, questions that have not been asked to develop understanding.

Our definition of understanding is a 'constant process of redefining and deepening, seeing things from new angles, making fresh connections' (Fleming 2001, p.61). This is not about joining the dots for learners. We conceive it instead in Stake's terms as 'more a matter of chronologies than of causes and effects' (Stake 1995, p. 39) and are in accord with Ricoeur's suggestion that what is needed to understand is imagination and intuition. Viewed from this perspective the understanding of leadership by individuals during the course was intersubjective and not '...an all or nothing affair' at a particular point in time (Fleming 2001, p.61).

Time was taken to establish a temporary understanding of leadership and management not as a mental process, but in the sense of 'Now I know how to go on'. We place emphasis on how participants learn 'how to go on' from the experience of recognizing other voices from a variety of positions and viewpoints. The fundamental nature of Kaleidoscopic pedagogy is that of polyphonic third space. Knowing how to go on, as a definition of understanding also implies a preceding period of uncertainty where, 'I did not know how to go on' or in Bhabha's terms, a Third Space experience (Bhabha 1994, p.37). By third space we refer to an artistically cocreated conceptual, physical site for transdisciplinary dialogue and informal learning especially critical reflection (Lehikoinen, Pässilä, Owens, 2015). Given that the form of critical reflection generated in Kaleidoscopic pedagogy is collective the approach moves beyond individual problem solving and challenges in cultivating organizational learning and from each other and so the possibilities of change and transformation. In the context of the course we were particularly interested in the potential of creating a third space site to co-construct 
understandings about management and leadership with those who were entering the field for the first time.

\section{Principles of equality in learning}

The participants on the leadership course improvised collectively through a series of Arts Based Methods in order to move beyond the known and co-create new knowledge through practice in collaboration with the four tutors each with different backgrounds. Each had significant expertise, but this was deliberately not foregrounded as kaleidoscopic pedagogy draws on the Rancièreian principles of learning. We see this as being determined by the extent to which democratic principles are established. Rancière, argues that equality should be the fundamental principle around which education should be founded and function (1991). And calls for a form of education which enables rather than actively disables the ability of the learner to construct: 'the path from what she already knows to what she does not yet know, but which she can learn as she has learnt the rest' (Rancière , 2009, p.14).

To create the space safe enough for participants to do this is a key challenge, to resist the conventional pedagogical stance of all of us involved as bridging experts, between our knowledge others deficit of understanding, for example in this case in terms of understanding of leadership and management. How to, in Rancière's words, 'uncouple' our 'mastery' from our 'knowledge' (2009); the educators art lies, he suggests the ways in which they allow others 'to venture in to the forest of things and signs, to say what they have seen and what they think of what they have seen, to verify it and have it verified' (2009, p.14) The ignorant educator, does not know what the learners should do or know.

Participation was thus a fundamental component in the course. For Rancière the means of achieving equality runs contrary to many accepted notions of what education might mean; the 'ignorant schoolmaster' polemic being a case in point (1991). Ignorance is cast as a virtue on the part of the educator. This is because equality disrupts traditional power relations in any education setting in Rancière's thesis; the expert in management and leadership is equal to all others in ignorance, all both refer - and defer - to the object of study as the source of knowledge. The expert is not the explicator, or the arbiter of understanding on the part of others, which Rancière argues is a disabling process, an additional layering of meaning to the original object of study, over which the expert has absolute control and thereby institutes an unequal and permanent power relations. (Adams and Owens, 2016)

In creating this argument Rancière problematizes several key terms that are normally associated with learning, most notably 'understanding'. Through the maintenance of inequality, understanding becomes constantly subject to validation by assessment, and this is under the absolute control of the explicator. The determination of understanding is wholly based on the mediation and packaging of knowledge that is presented to others, and ignores any new, original, idiosyncratic, personal or in our case collective interpretation that the students might bring to the analysis, since this may deviate from the 'correct expert' understanding provided, and potentially render it invalid. As he explains: 'Scholarly progression is the art of limiting the transmission of knowledge, of organising delay, of deferring equality' $(2011, p .8)$. This has much to do with creating in a Freirian (1970/2000) sense 'the space and time for learners to experience learning in their own terms' (Antonacopoulou, 2014). 
The conceptual learning framework which Kaleidoscopic pedagogy operated within during this course was simple but challenging: Firstly, we did not predetermine the arts based methods prior to meeting the group, but chose from a selection we thought might be appropriate based on our reading of the participants and the space we were working in. Secondly, methods were selected to enable participants to see what existed differently, critically, sometimes reflexively, by revising how they constructed ideas in relation to management and leadership. Thirdly we worked openly with the Rancièreian premise that equality is a starting point not an end goal so positioning the international diversity of the students as an opportunity not a problem in developing understandings of management and leadership. When the method began to stop learning we welcomed this and suggested a change, acknowledging that knowledge creation is a process.

Theoretically, Kaleidoscopic pedagogy can be interpreted as following the fundamentals of transformational leadership (Burns, 1978; Yukl, 1998). Although approaches to transformational leadership have been developed during the past decades, the main characteristics that differentiate transformational approaches from approaches of transactional origin have remained the same. Transformational approaches are based on processes and they do not separate leaders and the followers. Leadership is not only about individual development, but producing success at the community level (Schiuma, 2011). Transformational leadership is based on interaction and feedback with the emphasis on higher ideals and values and creating a feeling of justice and trust (Pässilä, Oikarinen and Kallio, 2013). Feelings of trust in our experience are essential for critical reflection.

\section{Impact and Experiences of Learning}

The difference the intervention made to learning and other impact is accounted for drawing on evidence from arts based evaluative methods. In this section of our chapter we start by describing in detail three situations where three different arts based methods were applied as a way to design the Kaleidoscopic pedagogical process. We say what we did, how we did it and why. We then discuss the impact and experiences of learning during the intervention from the students' and academic tutors' perspective, being mindful throughout of the experienced R\&D Manager's perspective. We move beyond the reviewing of practice by taking a reflexive approach. Reflexivity in this course was about helping the students collectively to learn and change as well as see how they avoid reflection in order not to learn or change. It highlights the paradox - the attempt to reflect collectively tends to mobilise simultaneously power relations that resist reflection. (Pässilä et al., 2015, p. 68).

Our extensive experience in using arts based methods has led us to the conclusion that 'less is more' when it comes to the use of the method itself. Instead we focus our energy and attention more on the overarching pedagogical in which we try and understand where the participants- in this case students- are, what might help them make their own connections. We do not pre-plan all the methods but respond in situ working according to the maxim that we are always well-prepared never over-planned. This mirrors the work we have done together with our experienced R\&D Manager team member with whom we have explored arts based methods, in the attempt to reach in to the challenging areas of her practice. What we are saying 
here is that we explain the three arts based methods that follow to provide examples about the ways in which we attempted to share the curiosity we had about given and emerging practices. They were not used only to illustrate existing theories of management and leadership but rather as part of a process that allowed the understandings of the students about management and leadership to grow.

Reflexive Sketch Books (Pässilä, Owens, Oikarinen, Kuusipalo-Määttä and Benmergui, 2017) were introduced at the start of the course to be used as episodic parts of a formal reflection process. The space in which the course was held was a typical big university class room, we re-arranged tables into a U-form with gaps between blocks of tables so that we could all see each other but still move in and out of a central space. On each table we placed sketching papers, pencils, water colors, brushes, book rings for making Reflexive Sketch Books and water cups and bubble water. At the rear of the class room we arranged a large table of specific artistic props including colored papers, more colors and pencils, hole punchers, scissors, glue, stamps, images, fabrics and ribbons.

We introduced Reflexive Sketch Books through action, organising a co-creation process where each of us made own sketch book by cutting or tearing papers, punching holes in papers and binding them together with the help of rings. We explained that the idea of all these props was to reshape space, to invite a playful convention to an academic learning space. We followed the pedagogical practice which Clive Holtham form Cass Business School, London together with one author of this chapter - Allan Owens have applied with postgraduate students of business \& theatre education over a 10-year period (2007-2017). Students and tutors on the management and leadership course were invited to a reflection process (Holtham, Owens and Bogdanov, 2008) that considers and values:

(1) the ability to critically, creatively reflect on self as: "I, the manager", "I the leader."

(2) the affordances of the artefacts used in the process of reflection, including analogue \& digital media

(3) the impact of sketchbooks on the learning processes

The following image is an example of art pedagogical props used in learning. 


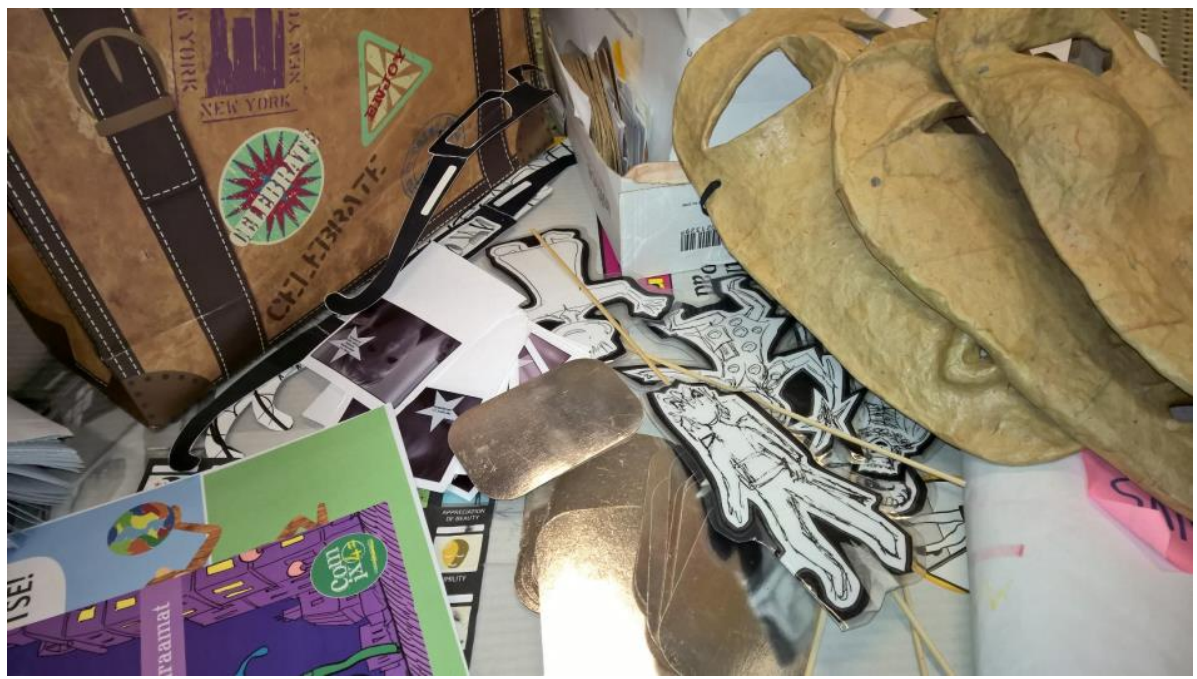

Image 2 Example of art pedagogical props used in learning

Each day we spent time during activities as well as during a final exercise at the end of each activity working in our Reflexive Sketch Books, we encouraged students to sketch and write during conventional lectures as well as arts based activities and share these with each other.

As facilitators we also created our own Reflexive Sketchbooks and organized discussions around them. This rooted reflection as a form of collaborative work in a very concrete way. The reason why this method was used was shared as an affordance to allow the students and us articulate our own problematizations, questions, interests, assumptions, dreams, fears and the kind of links we and they made to theory and practice.

"...the most unexpected and properly cool thing for my whole life was creating my own sketchbook. It is really very unusual for me to see this approach to education but I definitely like it. I could be creative. I could express my own thoughts. No one will tell you that you made a mistake. In my country xxxx we have a different approach to education."

"...as an xxxx student I am shy to express my thoughts in glass especially when as a question. Activities really me provided me with a chance to express opinions. The sketchbook really helped me to reflect on the course."

A few of the students struggled with the method finding it difficult to physically work away from A4 paper written text format and mentally difficult to select what was important form the divergent range of ideas being considered and discussed.

-"There will be initial skepticism:" I was very skeptical in relation to these artistic sketchbooks for personal gain because it was a very foreign concept to me. 
Our strategy was to keep doing this ourselves, encourage, keep on giving permission to be original, repeating the fact that the skills of drawing were not needed, encouraging the use of metaphor, magazine montage, juxtaposition and connection making in visual and written text forms. A number of these few struggled and found a way through over time.

...of the two days I started to appreciate this method."

(Extracts from written feedback from three students : anonymous)

The following image is an example of a one page of Reflexive Sketch Book where one student links leadership and roles to her/his own identity as a forthcoming professional. In this example the student questions the professional role rather than building it to a take-for-granted role. This is a typical outcome of impact achieved in our course, and we link this type of reflection to the critical thinking which emerged while students were working with their Reflexive Sketch Books.

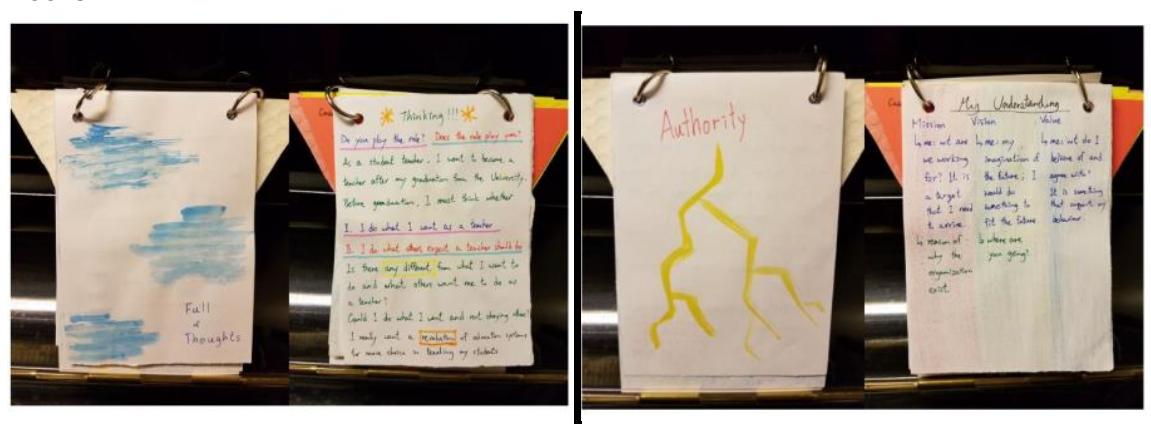

Image 3 Example of students own problematisation in a Reflexive Sketch book

In summary, the Reflexive Sketch Book was conceived of as a pre-text; in other words, it is an excuse to think, a giving of permission for systematic reflection (Owens, 2014). It is concrete platform where students form their own ideas and make connections with the help of art pedagogical techniques like painting, comics drawing, creative writing. It was difficult for a few participants but some of these found a way through and at the other end of the spectrum one students who was then supported by others said it would be hard to go back to A4 working and thinking after this experience.

In the second arts based method selected from the whole pedagogical process we describe how we applied a dramaturgical technique called Work Story \& Theatrical Images (Pässilä, 2012) to this educational context. The reason why we did this was to allow for an articulation of individual and collective understanding what was happening in learning situations during the course. Work Story \& Theatrical Images were constructed for use originally in organizational settings by Pässilä (2012) on the basis of the five elements of drama - act, scene, agent, agency, and purpose (Burke, 1969). They have been used subsequently in a wide range of business, organisational and educational settings (Pässilä 2012, Pässilä, Oikarinen and Kallio, 2013, Pässilä, Owens and Pulkki, 2016). In the context of this course the Theatrical images I the form of large cards were laid out on a large table and students were invited as a first step to choose a theatrical Image that resonated their experience in situ. They were invited to articulate a burning issues or passion about learning. The students then got in to pairs and shared this with each other by repeating their burning issue. They each did this for a couple of 
minutes with the help of theatrical image whilst walking around the room. This was repeated three times with three different partners. After this we discussed the issues that had been clarified through the repetition process collectively.

"[I]...found it strange and a bit uncomfortable at first but very necessary strange because the first time for example you repeat yourself it feels like a robot under the hand of realise actually clarify my own thoughts down logically in the discussion to the last time I repeat and much more likely to be clear to myself and to get my point across."

(Student feedback anonymous)

The theatrical images in this way generated stories that represented the experiences of the students; evoking and stimulating feelings about previous experiences in work that then formed the basis of (collective) reflection (Pässilä, 2012). Work Stories formed snapshots of understandings in relation to happenings in learning situations. In particular we aimed to notice and make sense of tensions, burning questions and implicit experiences based on the generation and gathering of meaningful and contextual understanding in the learning situation as a means of enabling the ability of the learner to construct 'the path from what she already knows to what she does not yet know, but which she can learn as she has learnt the rest' (Rancière, 2009, p.14).

The following images are examples of Theatrical Images used in the context of trying to understand and reflect on what is happening in a learning situation.
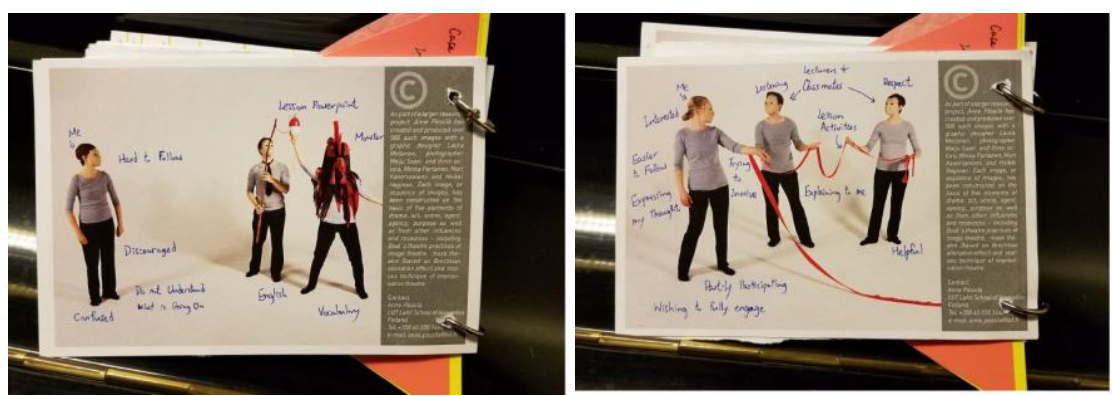

Image 4 Examples of Theatrical Images used in reflection

In summary this arts based method enabled the tutor to create dialogical relation with students and most importantly, the students with each other in order to systematically inquire as to where we were in terms of our understandings of the pedagogical process and about management and leadership. Reflecting after the course some students readily articulated what the processes flowing from the arts based methods allowed for:

"I believe that these processes are greatly help me understand leadership and management from a more holistic and personal level."

"I have learnt a lot in this course not just theoretical things that management and leadership about different ways of working."

For some students the challenge lay in making connections: 
"It was not always easy for me to find a link between management leadership and the topics we went through with arts-based methods."

(Student feedback, anonymous)

Thirdly we describe an arts based method arising from a particular situation which illustrates the idea of turning in Kaleidoscopic pedagogy. This happened on the last day of the course when one of the authors lectured in traditional academic format about American sociologist $\mathrm{C}$. Wright-Mills' concept of the sociological imagination (The Sociological Imagination Oxford: Oxford University Press, 1959) and in particular his notion of 'happy robots'. Following this lecture students were invited to watch a Charlie Chaplin film 'The Assembly line (1936) and were encouraged to a.) make their own critical interpretation of Wright-Mills definition of the happy robot and b.) what Wright-Mills might have meant by the statement that "cheerful robots are antithesis of democratic society ". The offer in other words was to do with "the awareness of the relationship between personal experience and the wider society " (1959). We then turned to embodied interpretation by inviting students use their bodies with imagination; moving together in pairs and exploring the scenario of how they see leadership in future and the needs it might be responding to. We introduced a basic contact improvisation technique with the rules that 1.) there was always physical contact between the partners 2.) there was always movement happening no matter how slight 3.) there was an acceptance of moves offered rather than blocking 4.) the music played should somehow be reflected in the movement created. In other words the student had a structure of what and how to do their embodied explorations. During the week we all together, students and tutors created this type of playful and trustfull space and repeated our contract of co-creation by checking and ensuring this was on track in various ways. However it is a challenge to create playful and trustful types of space as the next quotations again shows:

"I enjoyed arts-based methods I only wish there would have been more explanation why we are doing what we are doing-like when we were doing different kinds of postures on the last day and it was explained why. " and "I believe a greater focus on the end goal of the exercises would be of asset to the students."

(Written students feedback, anonymous)

The following image illustrates how students constructed their embodied interpretations. 


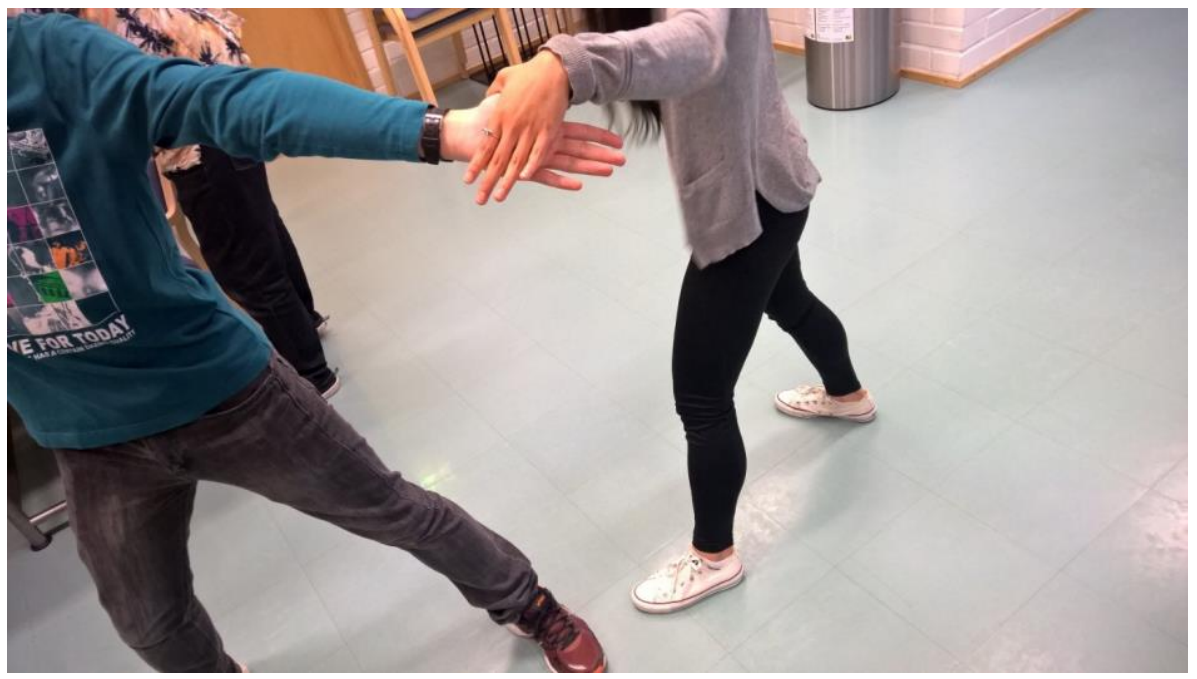

Image 5 Example of embodied interpretations

After the physical movement we watched the performances of movement asking, "What did you see and interpret through the movement in relation to leadership that is ethical and sustainable? In these discussions we as tutors were inquiring about student points of view, the main idea being 'to be curious 'of their thinking, creating space for dialogue and to make them curious about theory and craft of leadership.

These sequences in this one micro-pedagogical situation are examples of how we understand arts-based learning as a kaleidoscopic pedagogy where several turns are made in order to create understanding; we turned a) from using traditional academic lecture b) to using metaphor as an artistic interpretation c) to invite students cognitive thinking, after that we turned again from cognitive thinking d) to embodied interpretation.

\section{The impact and experiences of learning during the intervention from the students} perspective

The students wrote about their experiences of the course in the last hour of the last day. We framed feedback with the question: 'How did the experience of learning take place on this course' and tabulated their writings into the following categories: 1) Working with others/the relational, 2) Cultural diversity/ Relaxed positive atmosphere, 3) Creating opportunities for Independent thinking and 4) What are the impacts of learning? 5) What tutors learnt/ What are the potential drawbacks? Categories number 1-4 are presented in following table, and category 5 is presented independently.

\begin{tabular}{|l|l|}
\hline $\begin{array}{l}\text { Working with others/the relational } \\
- \text { I really like that we had a lot of teamwork } \\
\text { and not boring lectures }\end{array}$ & $\begin{array}{l}\text { Cultural diversity/ Relaxed positive } \\
\text { atmosphere }\end{array}$ \\
\hline
\end{tabular}


-I like this course combination of listening moving working in teams. This method makes it possible to be really involved in the process.

-through all the activities and discussion everyone was involved

- I observe that all students were active and participated in the class and could not see any students sleeping in class. This confirms how positively the activities contributed to the effectiveness of the class.

-the appreciation the teachers showed about the work of the students was outstanding. So much so that in the last two days I could not help to think that it was faked and forced by the teachers which took some of the magic away this insight I saw was a source of inspiration to me when teachers are this much involved with the students

\section{Creating opportunities for Independent} thinking

- I have really benefited from this course more especially the activities in the discussions that supported my thinking and a good digest of the lecture topic.

-this course is has helped me tremendously finding different ways to perceive information to experience information and to share it.

-of this course was a totally different experience for me is in my home university were taught in a different way they treated more like kids not like persons from whom the teachers can also learn something. Here I see that you are really interested in what I think. -while working with others I learned a lot about different cultures. I think the lectures highlighted the cultural diversity.

-I have a feeling that I know all of you for a long time

-I really feel comfortable in sharing my ideas in the course although I didn't understand everything in the class I still find this course so interesting.

\section{What are the impacts of learning?}

-I have really broken my horizons and have become more open minded.

-l learnt that I can change my way of thinking it can be adaptable to different situations

- when I chose this course I expected to get new knowledge and learn how to study management in Finland, but I got not only this and much more I received new impressions, this course inspired me to study management more.

-I really like this course it seemed to help with the learning process and making sense.

-methods help to make sense and seek face-to-face discussions without the presence of knowing the right answer which was very welcome.

\section{What tutors learnt/ What are the potential drawbacks?}

Whilst the course received extremely positive feedback rating we deliberately focus here on the critique of the course. We recognized that there is a need to explain more explicitly why we're doing what we're doing, to make connections and create more spaces for connections to be made, to expect and accept initial skepticism, to think more about the transitions between formal lecture and arts based methods, and to accept that the arts based approach will be rejected by a small number of the participants based on the following quotations from anonyms student feedback: 


\begin{abstract}
-" the blending connection between these lecturers with different approaches and activities really made the class active."

-" we had to slip over information. The two separate sides of the course artistic and lecture seemed separated."

-"generally I liked the arts-based methods, however for me it was too much. It was the only way of learning or board the only way practical exercises and it was too much sometimes alternatives would have been nice. I missed group discussion and particularly miseds the why question about how the activities connected to management and leadership and what the creative approach is about. It is hard to stay motivated and fully engaged in the course if you don't understand the purpose. Really missed connections. A middle way between lectures and activities would have been good."
\end{abstract}

We also recognize that the research dimension of the process needed to be handled with more care as part of the learning process.

-at some point it seemed like a game like with students were used for purposes of the research."

- "I had feelings of 'uncomfortability."

Initially in running the course we were surprised at how quickly most of the students appeared to adapt to new working methods and enjoy them. Experience in running three of these courses $(2015,2016,2017)$ has shown us that this is part of group dynamics in many courses when things are new tend to elicit positive responses. Whilst simultaneously enjoying this mode of energy we have come to know that another stage will follow in which while some students will be inspired by the new pedagogical approach other students will naturally question and be skeptical about the approach. We are very aware that mainstream thinking requires educators to convince students of the relevance of new methods, but resist this route and instead provide sufficient time for the students to reflect on the pedagogical, the theoretical background for using them and the space to consider if these methods really do offer the possibility to enhance their learning. Without space and time to reflect on the value of the pedagogical approach we are aware that the students could easily perceive the methods as warming up for more serious learning.

According to our experience Kaleidoscopic pedagogy allows students from different cultural background and disciplines to engage with the subject of management and leadership in ways that values their perspectives. Many students tend to undervalue their knowledge and hesitate to express their opinions, especially if the opinions are contradictory with the lecturers' message. Kaleidoscopic pedagogy allowed the students even from the cultures with a high power distance to share knowledge with the other participants, including lecturers. Having said this, from a tutors' point of view the challenge of organizing these third spaces in a Rancièreian sense is on-going and elusive.

\title{
Reflections and Developments
}

The lessons learned and reflections for using Kaleidoscopic pedagogy are ongoing, but to date, are as follows: exploring, researching and developing a form of pedagogy that speaks 
clearly to the needs of and practices in contemporary organizations is enhanced by the presence of a course tutor who brings contemporary reality of day to day management and leadership in to the design, implementation and evaluation of the course. The attempt to move beyond the model of arts use in organisations in which particular methods are applied to complex problems in order to achieve short term solutions is challenging. An arts based approach and methods for thinking and acting about management and leadership mobilise new possibilities and inspiration. At the same time, they generate a strong resistant undertow to keep things as they always have been in education; traditional teaching methods about management and leadership and Arts Based Pedagogy can be so at odds with each other that students fail to make their own connections. Some students will not find the Kaleidoscopic pedagogical approach and arts based methods within it useful whilst for others they will be transformatory.

A key challenge is to foster mutual responsibility between tutors and between participants in this dialogic process of transformation - and thus - naming the world (Freire, 1970/2000). Transformation through the process of learning generated through Kaleidoscopic pedagogical methods is a perpetually iterative and fundamentally social process that is reconstructed and redefined through multiple dialogic, polyphonic processes; these are visual and embodied as well as text based and can become the means through which participants become coinvestigators of knowledge and the world. They are invited to explore and name issues in their reality, reality being envisaged as a process, undergoing constant transformation.

The learning process which we view as being context specific is rarely replicable. In this sense, we are trying to move beyond the prevalent model of arts use in organisations in which shortterm, tool-box solutions in the form of particular methods are applied to complex problems, but recognise the value of examples.

This research has been undertaken as part of the ArtsEqual -project funded by the Academy of Finland's Strategic Research Council from its Equality in Society-programme (project no. 293199) and EU funded Erasmus + Strategic Alliance 2 -Partnership Project: Beyond Text.

\section{References}

Adams, J. and Owens, A. (2016), Creativity and Democracy in Education: the practice and politics of education through the Arts, Oxford, Routledge \& Taylor Francis Group.

Adler, N. (2015). "Finding Beauty in a Fractured World: Art Inspires Leaders-Leaders Change the World." Academy of Management Review, 40 (3), 480-494.

Antonacopoulou, Elena P. (2010), "Making the Business School More 'Critical': Reflexive

Critique Based on Phronesis as a Foundation for Impact", British Journal of Management,

21.

Antonacopoulou , E. (2014), "The experience of learning in space and time." Journal

Prometheus, 2014 Vol. 32, No. 1, 83-91, Downloaded on 15.12.2017 from :

http://dx.doi.org/10.1080/08109028.2014.945286 
Beyond Text (2016-2019), Erasmus Strategic Alliance Key Action 2,

https://www.chester.ac.uk/node/40087

Bhabha, H. (1994). The Location of Culture. London: Routledge.

Burke K. (1969), A Grammar of Motives. Berkeley: University of California Press.

Burns, J.M. (1978). Leadership. New York: Harper \& Row.

Cotter R.J., Pässilä, A. and Vince, R. (2015) New Directions for Researching Critical

Reflection in Organizations. In Jan Fook, Val Collington, Fiona Ross, Gillian Ruch,

Linden West (eds.) Researching Critical Reflection Multidisciplinary

Perspectives. Routledge.

Fleming, M. (2001). Teaching Drama in Primary and Secondary Schools. London: David

Fulton.

Freire, P. (1970/2000), Pedagogy of the Oppressed. New York: Continuum.

Gonnami,T. (1988). Images of Foreigners in Edo Period Maps and Prints. [Online] (URL

Patriot.lib.byu.edu/ERastAsianLibraries/image/6713152132008_1266224.PDF).

(Accessed 4 October 2013).

Gray, N. (1991). The Kaleidoscope: Shake, Rattle and Roll. The Australian Journal of Media and Culture, 6(2). [Online]. (URL

http//wwwmcc.murdoch.edu.au/ReadingRoom/6.2/Gray.html). (Accessed 25 th July 2005).

Harmaakorpi, V. and Melkas, H. (2012), "Epilogue: Two Modes of Practice-Based Innovation", in H. Melkas and V. Harmaakorpi (eds.) Practice-Based Innovation: Insights, Applications and Policy Implications, Heidelberg: Springer, pp. 437-452.

Holtham Clive, Owens Allan , Bogdanova Mariana, Holtham Susan (2008) “Visual Imagination in Professional Development". Imagining Business Conference, European Institute for Advanced Studies in Management, Said Business School, University of Oxford. 
Lehikoinen, K., Pässilä, A. and Owens, A. (2015), “Critical Reflection and the Arts as Third

Spaces", Conference paper in Organizational Learning, Knowledge and Capabilities conference, April, Milan, Italy $9^{\text {th }}-11^{\text {th }}$ April.

Murphy, J., Malin, V. \& Siltaoja, M. (2013), "Beyond critique: towards transformative practice in Critical Management Studies." Editors' Introduction." In Malin, Murphy \& Siltaoja (eds.) Getting Things Done. Dialogues in Critical Management Studies, Volume 2. Emerald Group Publishing Ltd.

Owens, A. (2014), "Translating and Understanding: pre-text based drama", in Korhonen, P. \& Airaksinen, R. (eds.) Hyvä Hankaus 2.0, Helsinki: Draamatyö, pp. 45-68.

Ostern, A.L. (2001). Drama and Theatreas arts Education.pp11-25. In: Organising Young People's Dramatic Practices. Aaltonen, H. and Ostern, A.L. eds. Jyvaskyla: Jyvaskylan Yliopistopaino Press.

Pässilä, A. (2012), Reflexive model of research-based theatre. Processing innovation at the crossroads of theatre, reflection and practice-based innovation activites, Acta Universitaties Lappeenrantaensis 492, Lappeenranta University of Technology, dissertation.

Pässilä, A., Oikarinen, T. \& Kallio, A. (2013), "Creating dialogue by storytelling." Journal of Workplace Learning, Vol. 25, No. 3, pp. 159-177.

Pässilä, A. \& Vince, R. (2015), "Critical Reflection in Management and Organization Studies." In Jan Fook, Val Collington, Fiona Ross, Gillian Ruch, Linden West (eds.) Researching Critical Reflection Multidisciplinary Perspectives. Routledge.

Pässilä, A. Owens, A. and Pulkki, M. (2016), "Learning Jam: An evaluation of the use of arts based initiatives to generate polyphonic understanding in work based learning", Higher Education, Skills and Work-Based Learning, Vol. 6 Issue: 2, pp.178-192.

Pässilä, A., Lehto, A., Laukkanen, A, Owens, A. and Benmergui R. (accepted 2017), "Beyond text - Embodied reading of data." Conference paper to be presented in the Participatory Innovation Conference 2018, Eskilstuna, Sweden 
Pässilä, A., Oikarinen, T. and Harmaakorpi, V. (2015) "Collective voicing as a reflexive practice." Management Learning, February 2015, vol. 46 no. 1, pp. 67-86.

Rancière, J. (1991), The Ignorant School Master: Five Lessons in Intellectual Emancipation

(Trans. Kristin Ross), Stanford, Stanford University Press.

Rancière, J. (2010), The Emancipated Spectator, London, Verso.

Schiuma, G. (2011), The Value of Arts for Business, Cambridge, Cambridge University Press. Stake, R. (1995). The Art of Case Study Research. Thousand Oaks: Sage Publications.

Sutherland, I. (2013), "Arts-based methods in leadership development: Affording aesthetic workspaces, reflexivity and memories with momentum", Management Learning, Vol. 44., No. 1 , pp. 25-43.

Taylor, S. and Ladkin, J. (2009), Understanding Arts-Based Methods: Managerial

Development, Academy of Management Learning and Education, Vol 8, No. 1, pp. 247-254.

New York: Routledge.

Vince, R. and Reynolds, M. (2009), "Reflection, Reflective Practice and Organizing

Reflection", in S. J. Armstrong \& C. V. Fukami (eds.) The SAGE Handbook of

Management Learning, Education and Development, London, SAGE.

Yukl, G. (1998). Leadership in Organisations. New Jersey: Prentice Hall.

Anne Pässilä Ph.D, is Senior Researcher at LUT, LSI Finland; Visiting Research Fellow of University of Chester, UK, and partner-entrepreneur in Susinno Ltd. Her expertise is in applying arts-based initiatives to support innovation and organisational development processes as well as arts-based research. Through her research on the reflexive model of research-based theatre she is contributing to the emergent field of 'arts-based management'. Anne's interests are in investigating a methodological approach in which arts-based initiatives are utilized to involve employees of organizations and networks in development work. http://www.annepassila.com

Allan Owens, PhD, is Professor of Drama Education, Co-Director of the Centre for Research in to Education, Creativity and Arts through Practice (RECAP), University of Chester, UK and a Higher Education Academy National Teaching Fellow. He has led long-term capacity building projects, run intensive short programs, developed research initiatives and staged pre-text based interactive performances in collaboration with colleagues locally and internationally. Allan specializes in the use of drama for understanding in the professions and his practice based research in the use of arts based initiatives in development processes is informed by extensive 
experience in creative pedagogy, drama, theatre and the intercultural. http://www.allanowens.com

Virpi Malin, PhD, is Pedagogical Director and a university lecturer at JSBE, Jyväskylä University School of Business and Economics. She has long experience in teaching and training both on the public and the private sector. In the academia she has acted as an organizer/facilitator in workshop sessions at the Academy of Management conferences for CMS, MED and TLC and at the International Doctoral Consortium in Halifax, Canada. Pedagogically and through research she wants to foster critical, reflexive and dialogical approaches that take both organizational and human interests seriously. https://www.jyu.fi/jsbe/yhteystiedot//sbe-faculty/malin-virpi 
